\title{
The Necessity for Regulating the Insurance Market Considering the Implementation of the IDD
}

\author{
Victoria Petsch \\ University of Applied Sciences Burgenland, Austria
}

\begin{abstract}
In 2018, the Insurance Distribution Directive (IDD) was fully implemented by all EU member states. It intends to harmonize the insurance market, provide the right incentives for the agents and protect the consumers. But why? The core business of the banking sector makes it necessary for a prudential authority to intervene and monitor. The question arises if the latest changes in the insurance business require these limitations and monitoring. This paper offers a literature review by compiling findings and setting up profound arguments, why the regulation of insurance companies is relevant. The main arguments for a strong prudential regulation are transparency, information asymmetry and agency problems, wrong incentives, a representation of the policyholder and the inversion of the production cycle. These findings make it necessary to regulate the companies and protect the policyholders. Further research should focus on case studies of insurance companies implementing the changes of IDD into daily business.
\end{abstract}

Keywords: Insurance Regulation, Prudential Authority, IDD JEL classification: G22, G28, G02, G15

\section{Introduction}

The financial market is regulated. The following chapter describes the latest history of insurance regulations. Furthermore, it gives a brief insight in the differences of regulating banks to insurance companies.

Since the foundation of the European Community in 1957 many directives were issued. They target a more integrated financial market and a harmonized approach (Cummins, Rubio-Misas \& Vencappa, 2017, p. 67). The past 25 years the financial market have undergone a deregulation process through the European Union's Third Generation Insurance Directive which was implemented in 1994. Creating a single European insurance market with a better diversification and a strong competition should have a positive effect on the choice of the policyholders with a variety of insurance products (Cummins et al., 2017, p. 66). The latest changes began with the consideration of Solvency II in 2007. This risk-based economic regulatory approach was implemented by European insurers. It is consistent for all member states. It aims at reflecting the risk that companies face and sets up a profound supervisory system. It not only focuses on the protection on customers but also on the stability of the financial system, especially the insurance industry (Cummins et al., 2017, p. 67). A significant transformation of the supervision of financial institutions occurred during the financial crisis in 2007 and 2008 (Doff, 2008, pp. 196-198). From then on, the European commission is constantly working for a harmonization of the regulatory framework across the EU member countries. This implies implementing standards to react to a rapidly changing market (Eling, M., Schmeiser, H., \& Schmit, J. T., 2007, p. 18). Solvency 
II, similar to the European banking regulatory framework Basel II, focuses on new requirements for insurers, provides the right incentives and is a risk-based approach (Doff, 2016, p. 604; Lorent, 2008, pp. 24-25). In 2018 the Insurance Distribution Directive (IDD) or RL 2016/97/EU was fully implemented by all EU member states. It is a directive issued by the Council of the European Union. The directive was developed as a consequence of regulatory changes. It intends to strengthen the consumer protection and establishes a competitive and harmonized landscape of the insurance business in the European Union (Directive (EU) 2016/97 of the European Parliament and of the Council).

The necessity for general financial regulation is well discussed in economic theory. In most of the literature, the focus lies in regulating banks rather than insurance companies. Many principles apply for financial institutions in general but there are differences in the nature of the two businesses (Konstantinides, 2003). The insurance sector and the regulations of insurance companies have evolved dramatically over the last years. These chances imply a strong connection to the banking sector (Lorent, 2008, p. 2). Das, Davies, and Podpiera (2003) state that the insurance business is traditionally seen as a stable financial sector. The liquidity liabilities within the banking industry increases the risk of contagious runs. Traditionally insurance companies are not affected by those runs (Das et al., 2003, p. 14, 2003, p. 3). Another evidence of a stronger bond between banks and insurance companies are partnerships and bancassurance. For over 20 years now, banks and insurers sell each other's products to grow through synergy effects. This cross-selling strategy initiated the development of complex risk management products, which is a challenge for the regulator to understand and evaluate them (Das et al., 2003, pp. 11-12).

Insurance companies offer products which are similar to saving products offered from banks (Lorent, 2008, p. 2). In the last years insurance companies transformed and positioned themselves as major actors within the financial market. New financial innovations modified the portfolios and increased the complexity of financial products. The liquidity risk and the systemic risk became higher. Life insurance products extended and became more similar to banking products. The new options within these products raised the liquidity of the liabilities. Because of these changes, there is now a clear difference to traditional insurance products, which reveals a new exposure (Lorent, 2008, pp. 24-25). Insurance companies generally have longer-term liabilities in comparison to banks (Das et al., 2003, p. 9). Implementing bank-type products is also a method of an insurance company to compete with other financial institutions on the market. These products bear higher risks and create more liquid liabilities in the financial statement. As a consequence, the insurance company needs to invest further in risky assets and is dependent on the economic growth of the market (Das et al., 2003, p. 3). In general, insurance companies have more liquid assets than banks, for example bonds, loans, real estate and equities. Therefore, insurers have a lower liquidity risk. Looking at assets and liabilities, a distinction between non-life and life insurance companies has to be made. Within the non-life sector, liabilities are short term. The claims that arise from non-life products are unpredictable in terms of occurrence and amount. The assets, which cover liabilities from a non-life item thus need to be of high liquidity. Therefore, non-life insurance companies hold more liquid assets than banks. Liabilities and assets within the life insurance sector are long-term oriented. The matching duration of assets and liabilities of their insurance products is a constant objective of the insurance company (Lorent, 2008, p. 8). Das et al. (2003) share this view in their research. The insurance industry changed and linked stronger to banks. This is especially supported through activities attributed to the banking business. The stated similarities between banks and insurance companies above tend 
to increase the vulnerability and endangers the financial stability of the insurance sector (Das et al., 2003, p. 3).

The core business of a bank makes it illiquid and fragile by nature. This is the reason for bank runs. Banks are connected within the interbank market and finance each other. Systemic panics may occur within the banking sector and cause global economic crises. In contrast to banks which invest in bank loans and bank deposits, insurance companies are more liquid with their investment in tradable assets. The reinsurance market reduces the contagion effect and prevent panics (Plantin \& Rochet, 2009, p. 2). Reinsurance plays an important role stabilizing the volatility and absorbing peaks of claims from big natural catastrophes. Reinsurance acts similar to a capital supplier to the insurers. Therefore, a failure of large reinsurance companies could result in contagions and have a high potential to disrupt the financial system (Das et al., 2003, p. 16). On the contrary, the interbank market can't dam the fragility and the contagion which occurs in the banking sector (Plantin \& Rochet, 2009, p. 2). However, insurance companies are not completely immune to crises (Das et al., 2003, p. 14). Considering the changing core business of insurance companies and the fact that insurance products become more similar to banking products, the industry is exposed to liquidity risk (Lorent, 2008, pp. 24-25). Lorent (2008) states that a stronger connection between the financial market and insurance companies is a danger for the economy. The insurance industry could face an insurance run as well. The systemic financial stability becomes more important and Lorent (2008) calls for a stronger supervisory framework on financial risks within the insurance market. Most literature and empirical evidence on insurance regulations ignores the fact of possible insurance runs. Morrison (2002) says that a run is no typical phenomena and cannot take place within the insurance sector. Another fundamental difference between banks and insurers, is the right of a policyholder in comparison to a depositor. Policyholders of insurance contracts often need to pay a compensation fee for possible withdrawal of the contract. The cancellation repayment of an insurance product is usually a longer period than for a bank deposit (Lorent, 2008, p. 8; Plantin \& Rochet, 2009, pp. 92-93). Furthermore, Lindgren, Garcia, and Saal (1996) differentiate between the possible scenario of panics and distress for a bank and for an insurance company. The big differences lay in the liquidity and the systemic risk. When a bank suffers from a financial distress the consequence is a liquidity problem. This happens because the liabilities of a bank are demandable deposits. As soon as the depositors think their deposits are unsafe, they'll withdraw their money. This was initially the reason for the implementation of security nets of central banks. DemirgücKunt and Detragiache (1997) argue that those systematic safety nets were responsible for emerging financial crisis. They develop a safe haven and support the moral hazard behavior of bankers. Often control systems are governmental owned, so the intention of exploitation rises. Banks that should have been closed in the past were saved because of political reasons (Plantin \& Rochet, 2009, pp. 90-91). Polonchek and Miller (1999) performed a detailed empirical study about the impact of the announcement of capital information for insurance companies. Announcing the emission of new capital is generally seen as bad news and has a negative impact within the banking sector. The stock price of other banks in the system is affected and contagion will occur if one bank suffers from distress. Polonchek and Miller (1999) didn't find any evidence for this contagion effect within the insurance sector. Statistically the contagion effect for insurers can happen but is very small in comparison to banks. Das et al. (2003) support this statement but differentiate for insurance companies with traditional products. For those insurers the contagion may be smaller. Depositors can withdraw their deposits immediately with small losses. If a bank might go bankrupt, 
depositors will take a higher future interest or a lower interest now to save their money. Channelling an insurance contract goes hand in hand with considering higher costs for potential claims and replacing the policy. The cancellation repayment of an insurance policy generally takes more time than repaying the bank deposit. For policyholders of traditional insurance products it is not convenient to take their money out of the insurance company (Das et al., 2003, p. 15).

Only looking at the core business of a bank and an insurance company, there is no need for stronger regulations on the insurance market. The liquidity and the systemic risk in the banking system are drastic but within the insurance sector much lower. Dewatripont and Tirole (1999) suggest to focus on the claimholder. With their representation hypothesis they state that the regulatory framework should act as a representative of the claimholder. Das et al. (2003) study big insurance failures in the past. They look at the factors that played an important role for the failures. The most important factor is the financial deregulation that allows the insurance company to perform bank-type activities and offer bank-similar products. Another factor described is the close linkage between banks and insurers (Das et al., 2003, p. 18). Insurance companies failed because they invested in risky assets such as junk bonds in order to meet the high return on liabilities. As soon as a recession in the economy emerged those risky investments became a high burden for the insurance company (Das et al., 2003, p. 20).

\section{Why regulate Insurance?}

The following section presents arguments, why the insurance industry needs to be regulated. Most of them would be missing in a free market and would result in negative consequences for shareholders, managers and policyholders. The International Association of Insurance Supervisors (IAIS) defines the Insurance Core Principles. They state that a regulatory system is necessary for a save and fair insurance sector. The focus lies on the protection and the interests of the policyholders and the overall stability of the financial system (IAIS, 2018, p. 4).

Lorent (2008) emphasizes the necessity of transparency. In comparison to other sectors, the insurance sector is in general less transparent. A high disclosure about the risk management is becoming increasingly important. The rising complexity of insurance products and internal models for transferring risk demand a higher level of transparent information (Lorent, 2008, p. 25). Borio et. al. (2004) also highlight the importance of market discipline connected with increased transparency. Regulations alone are not as successful for a strong and solvent insurance industry. A higher level of transparency creates a higher pressure on other insurance companies to provide their policyholders with appropriate products and services (Eling, Schmeiser \& Schmit, 2007, p. 17).

The phenomena of moral hazard and adverse selection is found in insurance institutions. A policyholder which has an insurance contract doesn't need to bear the full consequence of his or her behaviour. For example, a policyholder of a motor contract can drive faster and more irresponsible. In case of an accident, the policyholder doesn't need to bear the costs of repairing the car. The motivation to reduce the risk for an accident decreases when the risk is transferred to the insurance company. The insurance institution doesn't have any control on the behaviour of the policyholders. Otherwise, the insurance company also need to cope with information asymmetries. The policyholder has more information on his or her own level of risk than the insurance company. People with higher risk profiles are more willing to conclude an insurance contract than people with lower risk profiles. Because of the missing information about who has a high and who has low risk profile, the insurance 
companies price their contracts at an average level. Low risk profiles fund the highrisk profiles. Pricing the average risk profile works well, as long as low risk profiles won't decide to quit their contracts (Lorent, 2008, p. 5). Klein (1995) states in his public interest theory that regulations are necessary because of these imperfections in the insurance market. Regulators should prevent moral hazard and adverse selection and reduces the conflict of interest between the different parties of an insurance contract. Also Butsic (1994) says that a regulatory framework is needed to resolve market imperfections (Butsic, 1994, p. 658). Plantin and Rochet (2009) believe that market imperfections are the reasons for insurance regulations. The objective of the regulatory framework is to simulate perfect market conditions to save the policyholders and to compensate the existing agency problems (Plantin \& Rochet, 2009, pp. 27-28). During daily business, equity holders have the control right and take all relevant decisions about the company. In the case of an imminent insolvency the debtholders of an insurance company become the most important decision makers and take the control rights. They decide on the restructuring or the liquidation of the company. This is an understandable process and therefore it would be obvious to write this down in the corporate contract and implement this procedure within the management. This would be independent of the future leading management and could support quickly, making the right decisions when necessary. But because is seems to be difficult to include possible future actions, contracts stay incomplete (Plantin \& Rochet, 2009, p. 59).

Plantin and Rochet (2009) say that agents don't have the right incentives to act correctly in the case of distress. Prudential supervision seems pointless when people e.g. shareholders and managers with control rights and the necessary information don't act correctly because of a wrong incentive system (Plantin \& Rochet, 2009, p. 12). A case study showed that implementing the wrong incentives build unprofitable companies. Passive shareholders, short-term planning and hiring agents without a performance-based model support the downfall conditioned by wrong incentives (Plantin \& Rochet, 2009, p. 14).

The International Association of Insurance Supervisors state that the principle objective of supervision is the protection of the policyholder (IAIS, 2018, p. 17). Policyholders don't know how their paid premiums are used. Policyholders are as well not capable of evaluating the financial stability of the insurance company (Dewatripont \& Tirole, 1999). This is because insurance companies are too complex for policyholders to understand the processes behind (Plantin \& Rochet, 2009, pp. 27-28). Consumers are generally not interested in the profits of the firm. They just want the insurance company to pay their claims at the right moment. They want to be sure that the insurance company is capable of paying the claims during the lifetime of the product. Regulations should guarantee that the insurance company meets its obligations and protects the policyholder (OECD, 1998). Policyholders are not able to protect themselves against the insolvency of insurance companies by holding a diversified portfolio with more insurance companies to compensate one collapse (Cummins, 2002). Generally, policyholders rely on one insurance company for every insurance contract (Lorent, 2008, pp. 5-6). Policyholders can't use their control rights in practice. Therefore, a regulatory framework within the prudential authority needs to support the policyholders. This should be the representative of the policyholders and their claims in the governmental structure. During the time of distress, the regulator should function as a proxy and play the role of a claimholder, in order to protect their interests (Plantin \& Rochet, 2009, p. 63). Another reason for prudential regulations is that claimholders will always demand the payment of their claims. This is independent of the financial situation of the insurance company and wherever the company fears 
an insolvency. If a claimholder would be willing to cut his or her losses in time of distress, the liquidity problems could be dammed easily (Plantin \& Rochet, 2009, pp. 27-28).

One reason why insurance companies face agency problems is the inversion of the production cycle in the insurance industry. The distinctiveness of the insurance industry in comparison to other goods and services is that the insurance service is required long time after the product is purchased. Typically, premiums are paid by the policyholders when the contract is signed and permanently during the lifetime of the product. The compensation is paid by the insurer in case of an existing claim. This may happen after several years or probably never (Plantin \& Rochet, 2009, pp. 43-44). In case of a claim the insurer intermediates the risk directly. They use tools like diversification and risk pooling to manage the risk (IAIS, 2018, p. 4). The process of paying premiums in advance is applied because the premiums can't be collected afterwards, especially not for policyholders who didn't experience a claim or a loss. The actual production costs of insurance products can only be defined long time after the contracts have been underwritten and the corresponding premiums are paid (Plantin \& Rochet, 2009, pp. 43-44). Another feature of the inverse production cycle of the insurance industry is that the insurers can alter the risk profile during the existing contract. Policyholders could experience changes in their policies due to changes of the company, without the possibility to intervene for the policyholders (Plantin \& Rochet, 2009, pp. 53-54). Moreover, the inversion of the production cycle motivates managers to compensate difficulties by taking riskier policies with higher premiums. Losses don't automatically result in insolvency. Managers can react and take higher risks to compensate imminent losses (Plantin \& Rochet, 2009, pp. 27-28). The inversion of the production cycle creates dangerous agency problems. These can be mitigated by introducing a regulatory framework and capital requirements for insurance companies (Plantin \& Rochet, 2009, pp. 53-54).

\section{Conclusion}

A regulatory structure matters when the system suffers from agency problems and information asymmetries. The inverted production cycle and the time difference between purchasing a contract and getting the output in the insurance sector is the reason for the existence of these problems. Therefore, insurance companies need to be highly capitalized and exhibit a high liquidity. Unfortunately, this is not enough. Shareholders, managers and policyholders don't have the right incentives to make the right decisions when the company is in distress. Therefore, an external regulatory framework needs to be introduced (Plantin \& Rochet, 2009, pp. 53-54). The main reasons presented above strengthen the necessity of prudential regulations. Plantin and Rochet (2009) emphasize that introducing a strong regulatory authority doesn't imply the elimination of failures. In general, failures are important in the economy to identify and distinguish between efficient and inefficient firms. Moreover, reducing failures is a necessary objective for managers, which most of the time isn't contained in their incentive model. When the consequence of a failure happens, usually this is expensive and has a negative impact on the employees and policyholders. Therefore, it is relevant to set up a model that reduces failures but doesn't eliminate them completely. Without any failures, insurers would stop taking risks and start abandoning their core business. The solvency requirements would be huge and therefore financial services within the insurance market would be extremely costly. Regulations should supervise and intervene when insurance companies need to be restructured, but don't eliminate the free market and therefore the possibility for insurance companies to fail (Plantin \& Rochet, 2009, pp. 57-58). Gaganis and Pasiouras (2013) point out the power of a unified supervisory structure for the financial market. This structure creates 
synergies and is more efficient when it comes to functions and expertise. Additionally, it prevents regulatory gaps and duplicated control functions. A unified system sets clear responsibilities and increases the commitment of the supervisor (Gaganis \& Pasiouras, 2013, p. 5464).

Otherwise, there are situations in the insurance industry where regulating is not needed because the parties don't face agency problems. This is the case when a large and experienced broker makes a contract with an insurance company on behalf of his or her policyholder. When no regulations are present, the broker would not enter into a contract with an insurance company which credit rating is low. One option would be to reduce the premium for the policyholder in order to compensate the higher default risk of the insurer. Because the broker represents the policyholder and acts in his or her name, the broker would not do business with a company being poorly capitalized. In summary, when the policyholder is represented by a broker, the decision to enter into a contract or not in a free market are similar to a regulatory based system. Generally, prudential authorities differ from brokers in many points. A regulator checks the capital adequacy of the insurer and makes important reorganization or liquidation decisions (Plantin \& Rochet, 2009, p. 58).

By the end of 2018 the Insurance Distribution Directive (IDD) was fully implemented by all EU member states. This directive intends to harmonize the insurance business in the EU, provides the right incentives for sales agents and protects the policyholders. The main arguments presented in this literature review are covered in the IDD. Those are transparency, information asymmetry and agency problems, incentives, a representation of the policyholder and the inversion of the production cycle.

\section{References}

1. Borio, C. E. V., Hunter, W. C., Kaufman, G. G., Tsatsaronis, K. (2004), Market discipline across countries and industries. Cambridge, MIT Press, MA.

2. Butsic, R. P. (1994), "Solvency Measurement for Property-Liability Risk-Based Capital Applications", The Journal of Risk and Insurance, Vol. 61, No. 4, pp. 656-690.

3. Cummins, J. D. (2002), Deregulating property-liability insurance: Restoring competition and increasing market efficiency, AEl-Brookings Joint Center for Regulatory Studies, Washington, D. C.

4. Cummins, J. D., Rubio-Misas, M., Vencappa, D. (2017), "Competition, efficiency and soundness in European life insurance markets", Journal of Financial Stability, Vol. 28, pp. 66-78.

5. Das, M. U. S., Podpiera, R., Davies, N. (2003), "Insurance and Issues in Financial Soundness", IMF Working Papers: Working Paper No. 03/138, International Monetary Fund, Washington, D.C.

6. Demirgüc-Kunt, A., Detragiache, E. (1997), "The determinants of banking crises: evidence from developing and developed countries", World Bank Publications, Vol. 106.

7. Dewatripont, M., Tirole, J. (1999), The prudential regulation of banks, 2nd Edition, The Walras-Pareto lectures: Vol. 1. Cambridge, MIT Press, MA.

8. Doff, R. (2008), "A Critical Analysis of the Solvency II Proposals", The Geneva Papers on Risk and Insurance - Issues and Practice, Vol. 33, No. 2, pp. 193-206.

9. Doff, R. (2016), "The Final Solvency II Framework: Will It Be Effective?", The Geneva Papers on Risk and Insurance - Issues and Practice, Vol. 41, No. 4, pp. 587-607.

10. Eling, M., Schmeiser, H., Schmit, J. T. (2007), "The Solvency II process: Overview and critical analysis", Risk Management and Insurance Review, Vol. 10, No. 1, pp. 69-85.

11. Directive (EU) 2016/97 of the European Parliament and of the Council (2016), of 20 January 2016 on insurance distribution, Official Journal of the European Union 19, European Parliament and Council, 20.01.2016. 
12. Gaganis, C., Pasiouras, F. (2013), "Financial supervision regimes and bank efficiency: International evidence", Journal of Banking \& Finance, Vol. 37, No. 12, pp. 5463-5475.

13. International Association of Insurance Supervisors (IAIS) (2018), "Insurance Core Principles: Standards, Guidance and Assessment Methodology", available at: www.iaisweb.org (04 April 2019).

14. Klein, R. W. (1995), "Insurance Regulation in Transition", The Journal of Risk and Insurance, Vol. 62, No. 3, pp. 363-404.

15. Konstantinides, G. (2003), Handbook of the economics of finance. Handbooks in economics: Vol. 21, Amsterdam u.a.: Elsevier.

16. Lindgren, C.-J., Garcia, G., Saal, M. I. (1996), Bank soundness and macroeconomic policy, International Monetary Fund, Washington, D. C.

17. Lorent, B. (2008), "Risks and Regulation of Insurance Companies: Is Solvency II the Right Answer?", Working Papers CEB 08-007. RS, Université Libre de Bruxelles.

18. Morrison, A. D. (2002), The Economics of Capital Regulation in Financial Conglomerates, University of Oxford, Merton College and Saïd Business School.

19. OECD (1998), Competition and Related Regulation Issues in the Insurance Industry, available at: http://www.oecd.org/regreform/sectors/1920099.pdf (04 April 2019).

20. Plantin, G., Rochet, J.-C. (2009), When Insurers Go Bust: An Economic Analysis of the Role and Design of Prudential Regulation, Princeton University Press, Princeton.

21. Polonchek, J., Miller, R. K. (1999), "Contagion Effects in the Insurance Industry", The Journal of Risk and Insurance, Vol. 66, No. 3, pp. 459-475.

\section{About the author}

Victoria Petsch is a PhD student at the University of Applied Sciences and the University of Sopron. Before joining the International Joint Cross-Border PhD Programme in International Economic Relations and Management she studied International Business Administration, Psychology and Financial Management \& Controlling. Victoria gained experience in the insurance sector working for Allianz Austria as a strategic sales specialist. Now she is working as Project Management Officer for Central and Eastern Europe within the Allianz Headquarter in Munich. Victoria is focusing on strategic sales topics and conduct her researches in the field of insurance regulation. The author can be contacted at victoria.petsch@hotmail.com. 